\title{
Detection and Monitoring of Surface Motions in Active Open Pit Iron Mine in the Amazon Region, Using Persistent Scatterer Interferometry with TerraSAR-X Satellite Data
}

\author{
Marcos E. Hartwig ${ }^{1, *}$, Waldir R. Paradella ${ }^{1}$ and José C. Mura ${ }^{2}$ \\ 1 Remote Sensing Division, National Institute for Space Research (INPE), Astronautas Avenue, \\ 1758, Jardim da Granja District, São José dos Campos, SP 12227-010, Brazil; \\ E-Mail: waldir@dsr.inpe.br \\ 2 Image Processing Division, National Institute for Space Research (INPE), Astronautas Avenue, \\ 1758, Jardim da Granja District, São José dos Campos, SP 12227-010, Brazil; \\ E-Mail: mura@dpi.inpe.br \\ * Author to whom correspondence should be addressed; E-Mail: meh@dsr.inpe.br; \\ Tel.: +55-12-3208-6442; Fax: +55-12-3208-6449.
}

Received: 12 August 2013; in revised form: 3 September 2013 / Accepted: 10 September 2013 / Published: 18 September 2013

\begin{abstract}
Persistent Scatterer interferometry (PSI) represents a powerful tool for the detection and monitoring of tiny surface deformations in vast areas, allowing a better understanding of its triggering mechanisms, planning of mitigation measures, as well as to find better solutions for social and environmental issues. However, there is no record hitherto of its use in active open pit mine in tropical rainforest environment. In this paper we evaluate the use of the PSI technique for the detection and monitoring of mine slope deformations in the N4W iron mine and its surroundings, Pará State, Northern Brazil. The PSI processing was performed with 18 ascending SAR scenes of the TerraSAR-X satellite acquired in the dry season of 2012. The results showed a significant number of widely distributed persistent scatterers. It was observed that most of the study area was stable during the time span. Nevertheless, high deformation rates $(312 \mathrm{~mm} /$ year $)$ were mapped over the mine waste piles, but do not offer any hazard, since they are expected displacements of meters in magnitude for these manmade land structures. Additionally, it was mapped tiny deformation rates in both the east and west flanks of pits 1 and 2. The main underlying reasons can be assigned to the accommodation phenomena of very poor rock masses, to the local geometric variations of the slope cuts, to the geological contact between ironstones and the country rocks, to the exploitation activities, as well as to the
\end{abstract}


major geological structures. This study showed the applicability of the PSI technique using TerraSAR-X scenes in active open pit mines in tropical moist environment. However, the PSI technique is not capable in providing real-time warnings, and faces limitations due to SAR viewing geometry. In this sense, we strongly recommend the use of radar scenes acquired in both ascending and descending orbits, which would also provide a more complete understanding of the deformation patterns.

Keywords: persistent scatterer interferometry; surface deformation monitoring; open pit mine; tropical environment; Carajás Mineral Province

\section{Introduction}

One of the most important open pit iron mines in Brazil is the N4W, located in the Carajás Mineral Province, Amazon Region (Figure 1). Its production in 2010, together with the N4E and N5 iron mines, were equivalent to US $\$ 8.7$ billion [1]. The N4W mine has shown some slope instabilities in the last few years [2], which caused concerns in the resident geotechnical team of the Vale S.A. mining company. In order to avoid such a problem, geotechnical monitoring systems in areas considered as critical are usually employed. In spite of being known for having a high precision, these traditional techniques present operational, logistical, and economic disadvantages, such as the cost against the size of the monitored area [3-5]. In this sense, the persistent scatterer technique, PSI [6,7], which uses the phase information (proportional to the sensor-target distance) of SAR (Synthetic Aperture Radar) scenes acquired at different times (from the past to the present depending on the availability of the scenes), provides a synoptic view of the distribution and the activity status of unknown surface motions [8-14]. This approach consists in identifying statistically pixels, which include stable scatterers (e.g., outcrops, manmade structures, etc.) from a relatively large number of SAR scenes $(>15)$, based on its reflectivity pattern, allowing use of them as benchmarks.

In this work the PSI technique was used for the mapping and monitoring of surface displacements of the N4W iron mine, and its surroundings (e.g., infrastructure, roads, mine waste piles, etc.). For this purpose a set of orbital SAR data was processed, which consisted of 18 TSX-1 (TerraSAR-X) complex scenes acquired during 11 days during the dry season of 2012. The N4W mine has approximately an area of $4 \mathrm{~km}^{2}$ and $300 \mathrm{~m}$ in depth and is comprised of poor rock masses [15], where crops out archean ironstones (Fe content as high as 66\%) and metavolcanic rocks striking N-S included in the Grão Pará Group [16,17].

This work is organized as follows. In Section 2, is presented the geological and tectonic settings. In Section 3 the lithostructural and geomechanical features of the N4W mine, as well as its instabilities records are described. In Section 4 the fundamentals of the PSI technique is presented. In Sections 5 and 6 the dataset used and the results obtained are described. In Section 7 we discuss our findings from a geological perspective and in Section 8, we present some concluding remarks.

This study is part of an innovative research among INPE-FAPESP-Vale that aims for the application of orbital radar imaging to the detection of possible surface displacements affecting the active open pit iron mines of the Carajás Mineral Province, Pará State, Northern Brazil. 
Figure 1. Location of the study area with indications of the main mineral deposits of the Carajás Mineral Province and the Itacaiúnas Shear Belt, Northern Brazil. Adapted from $[16,18,19]$.

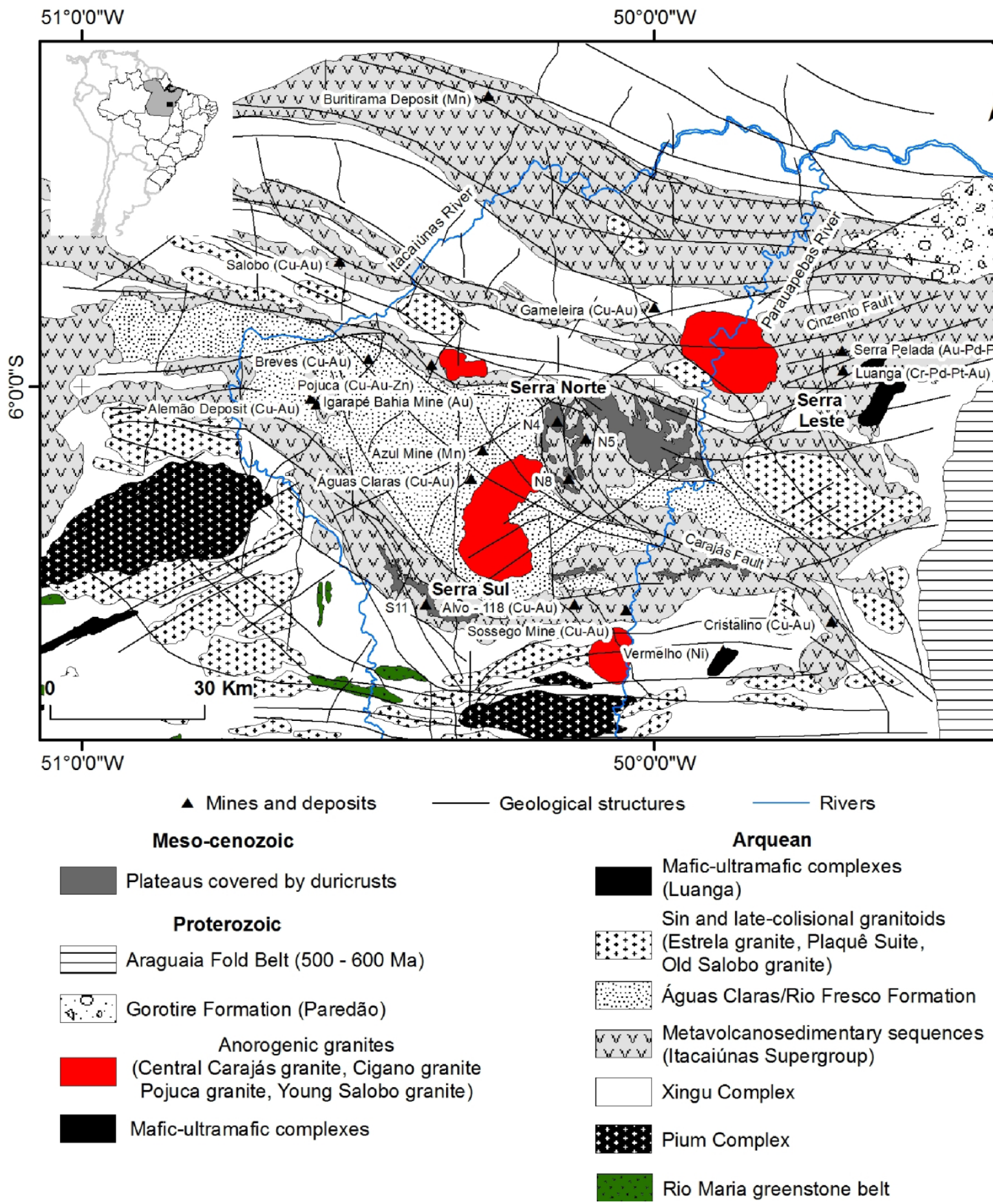

\section{The Carajás Mineral Province}

The Carajás Mineral Province (CMP) is one of the most important mineral reserves in Brazil, containing the world's largest iron deposits (18 billion of tons with an average content of $66 \% \mathrm{Fe}$ ), besides $\mathrm{Cu}, \mathrm{Au}, \mathrm{Mn}, \mathrm{Ni}, \mathrm{Zn}$, and Pt [20]. The CMP lies along the Itacaiúnas Shear Belt (ISB) with E-W-trending (Figure 1) [21], which was originated in a ductile sinistral transpressive event (2.8 Ga) 
that initially affected basement rocks, reactivated until early Phanerozoic times [19,22]. The ISB comprises a mid-Archean basement containing gneiss and migmatites of the Xingú Complex and orthogneisses of the Pium Complex. The basement is unconformably overlain by a low-grade volcanic and sedimentary rock of the Itacaiúnas Supergroup and layered mafic-ultramafic complexes [23]. Over the cover assemblage lies marine to fluvial clastic rocks (e.g., arenites, siltites, calcarenites, and conglomerates) of the Rio Fresco/Águas Claras and Gorotire (Paredão) formations [22,24-26].

The metavolcanosedimentary sequences of the Itacaiúnas Supergroup are divided into five groups: Grão Pará, Igarapé Salobo, Igarapé Pojuca, Igarapé Bahia, and Buritirama [16]. The Grão Pará Group $(2.76 \mathrm{Ga})$ [27] comprises a large amount of volcanic rocks (basalts, andesites, and riolites) and ironstones grouped in the Parauapebas and Carajás formations. The large iron deposits found in the region are included in the jaspilites and iron ores (hematite) of the Carajás Formation, and can reach up to a thickness of 400 meters [20,28,29].

The CMP was also subjected to intense granitic magmatism most of them from Archean ages (3.0 to $2.5 \mathrm{Ga})$ and Paleoproterozoic ages $(1.88 \mathrm{Ga})$ [30,31]. Many of the mineral concentrations found in the CMP were influenced by granitic intrusions [32]. In addition to the granitic magmatism, the CMP was also intruded by mafic sills and dykes $(2.64 \mathrm{Ga})$ [33] attributed to a sin-depositional vulcanism of the "Grão Pará" Basin [34], as well as to a regional distension event during Mesoproterozoic [35].

\section{The N4W Mine}

In the N4W mine a few lithological units, that can be briefly described as follows, were mapped. In its core, crops out ironstones (banded iron formations and jaspilites), surrounded by metavolcanic rocks (andesite, basalt, and rhyolite) dipping to the west. Basic dykes and sills are emplaced into these units that are covered by thickly layered iron duricrusts and laterite soils. Weathered rocks predominate and show varying degrees of alteration that are responsible for the differences in hardness. Recognized in [15] are four main structural features in the N4W mine (notation dip direction/dip): (a) joints with variable attitudes affecting all units; (b) banding with attitudes of 275/41; (c) ductile shear faults with attitudes of 275/43 and 104/41; and (d) faults with attitudes of 015/60.

Reference [36] presented the results of strength tests for the main units of N4W mines, backanalysis of slope failures, and data compiled from other studies. The results showed that the bulk of the units are classified as soft ground $(<250 \mathrm{kPa})$ [37]. According to [15], in the N4W mine crops out mainly rock masses of very low geomechanical quality, RMR V and IV [38], while fair to very good rock masses (RMR III to I) crop out locally as isolated bodies.

\subsection{Slope Instability Records}

Reference [2] describes that the slope cuts of N4W mine were subjected to four large planar to circular failures between the years 2003 and 2008 (Figure 2). The authors mentioned that the failures were due to the effect of "hidden" geological features (the geological contact between banded iron formations and mafic sills/dykes dipping into the pit) and to the loss of slope base support due to the mining of the pit face. The authors do not mention any rain preceding the slope failure events. 
Figure 2. Slope failure due to a geological fault involving at least four cut slopes of the east flank of Pit 1 . Note the dismantling of the slopes due to erosional effects, which indicates the dominance of low-cohesion materials. Picture taken on 15 March 2012.

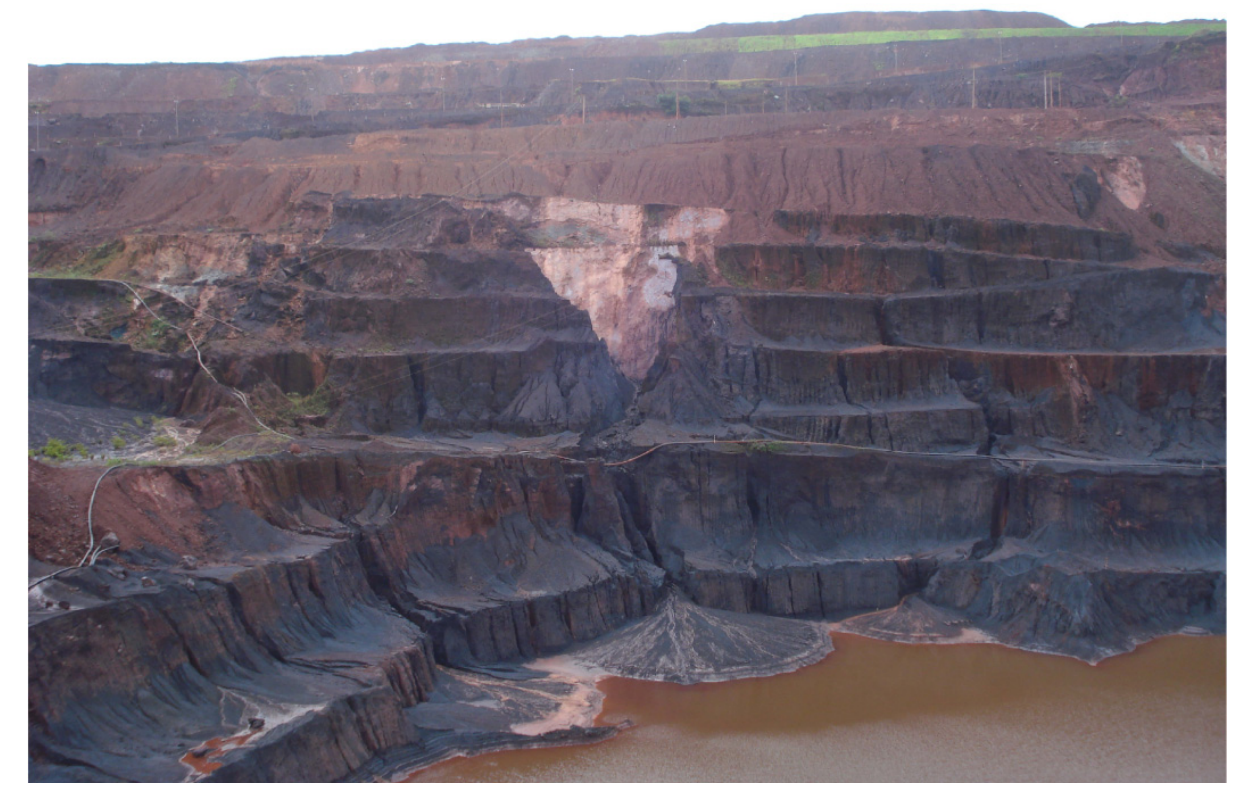

\section{Persistent Scatterer Interferometry}

Unlike optical imaging systems, the radar systems are responsible for producing their own source of energy, present lateral viewing geometry, and operate within microwave frequencies (electromagnetic wavelength, $\lambda=1-100 \mathrm{~cm}$ ). SAR systems capture the amplitude and phase signal backscattered from ground targets and store it as a digital complex number for each resolution cell of an illuminated scene. The amplitude of the backscattered signal represents the reflectivity of the targets and depends on target and system parameters, such as geometry, dielectric constant, roughness, etc. On the other hand, the phase of the signal indicates the cycle stage in which the wave is at a given moment. This angular quantity varies from 0 to $2 \pi$ radian and depends, among other things, on the sensor-target distance [39].

SAR interferometry (InSAR) is a remote sensing technique, which exploits the phase differences of homologous pixels of SAR scenes, acquired from different spatial and temporal positions. The temporal and spatial distances are known as baseline. The combination of two or more SAR scenes in an interferogram represents a map of phase differences. The InSAR technique was first applied to map the surface topography [40]. Years later, [41] used a similar approach to measure surface displacements in California, USA, what became known as DInSAR (Differential SAR Interferometry). DInSAR exploits the phase differences of two or more SAR scenes. However, it can be seriously affected by the atmosphere, which led to the development of the so-called permanent scatterers interferometry, PSInSAR ${ }^{\mathrm{TM}}$ [6,7]. This technique assumes that the reflectivity of some targets, such as outcrops, manmade structures, etc., keep stable during time. These targets, called permanent or persistent scatterers (PS) can be identified statistically based on their phase and amplitude stability in the time domain. However, the interferometric phase differences of each target in the interferogram " $i$ " bears some contributions [13]:

$$
\Delta \phi_{\mathrm{i}}=(4 \pi / \lambda) \Delta \mathrm{R}+\alpha+\mathrm{n}+\phi_{\text {topo }}
$$


where, $\Delta \mathrm{R}=$ target displacement, $\alpha=$ atmosphere, $\mathrm{n}=$ noise due to decorrelation and $\phi_{\text {topo }}=$ phase residues due to the digital elevation model (DEM) inaccuracies. A DEM is used in the processing chain in order to remove the topography phase related contribution from the interferograms. Thereby, the goal of the technique is to isolate the component due to deformation from the other contributions. This can be done by exploiting the characteristics of each one of the components in the space and time domains. For this purpose, it is necessary to generate a sufficient number of interferograms ( $>15$ SAR pairs), which allows to reach milimetric precision for displacement measurements. A comprehensive and recent review of this subject can be found in [42,43].

Currently, there are many approaches which use this principle [44-48], being collectively designated as persistent scatterers interferometry (PSI). An important aspect of the PSI technique is that its results (measures of the distances between the sensor and the ground targets) are not absolute in time and space domains, but are referred to as a "master" scene in time, and calculated with respect to a reference stable point in space.

Like traditional geotechnical monitoring systems, the PSI technology faces some limitations [10]. The first of them is that it is only capable of measuring displacements in the line-of-sight (LOS). In order to derive the E-W (PSI technology is not sensible to N-S displacements) and the vertical deformation vectors, it is necessary to combine SAR scenes acquired from both ascending and descending orbits. Another limitation of the PSI technique is the maximum detectable displacement, which depends on the electromagnetic wavelength, the temporal resolution and the spatial density of the scatterers. The last factors that pose strong restrictions to the use of the PSI technique are the temporal decorrelation of the SAR scenes, phase unwrapping problems and spatial gaps among scatterers.

\section{Dataset}

In this work were processed 18 TerraSAR-X complex scenes at full resolution (ascending orbit; StripMap mode; polarization $\mathrm{HH}$; incidence angle $=41^{\circ}$ (center of the scene); temporal resolution $=11$ days; $\lambda=3.1 \mathrm{~cm}$ ), acquired in the dry season of 2012, from March to September. The location of the study area within the footprint of the TSX-1 is indicated in Figure 3. Using a panchromatic high-resolution (0.5 m) GeoEye-1 stereopair, acquired over Carajás on 1 July, 2012, a DEM with Root Mean Square error in elevation of $1.5 \mathrm{~m}$ and pixel spacing of $2 \mathrm{~m}$ was produced in order to model the topographic phase [49]. The SAR scenes were processed in the GAMMA software, IPTA module [48]. The map projection used in this work is the WGS84-UTM22S.

\section{Results}

The cut slopes of the N4W mine and its surroundings show a great variety of orientations due to the pit geometry. Even though, dominates slopes dipping to east-southeast and west-southwest (Figure 4a). Slopes striking N-S dipping more than 41 degrees, to the east, are affected by shadows (Figure $4 b$ ), while slopes striking N-S dipping to the west are prone to be affected by foreshortening phenomena. Both geometric distortions limit the use of the PSI technique. 
Figure 3. Footprint of TSX-1 with indication of the N4W mine and its surroundings.

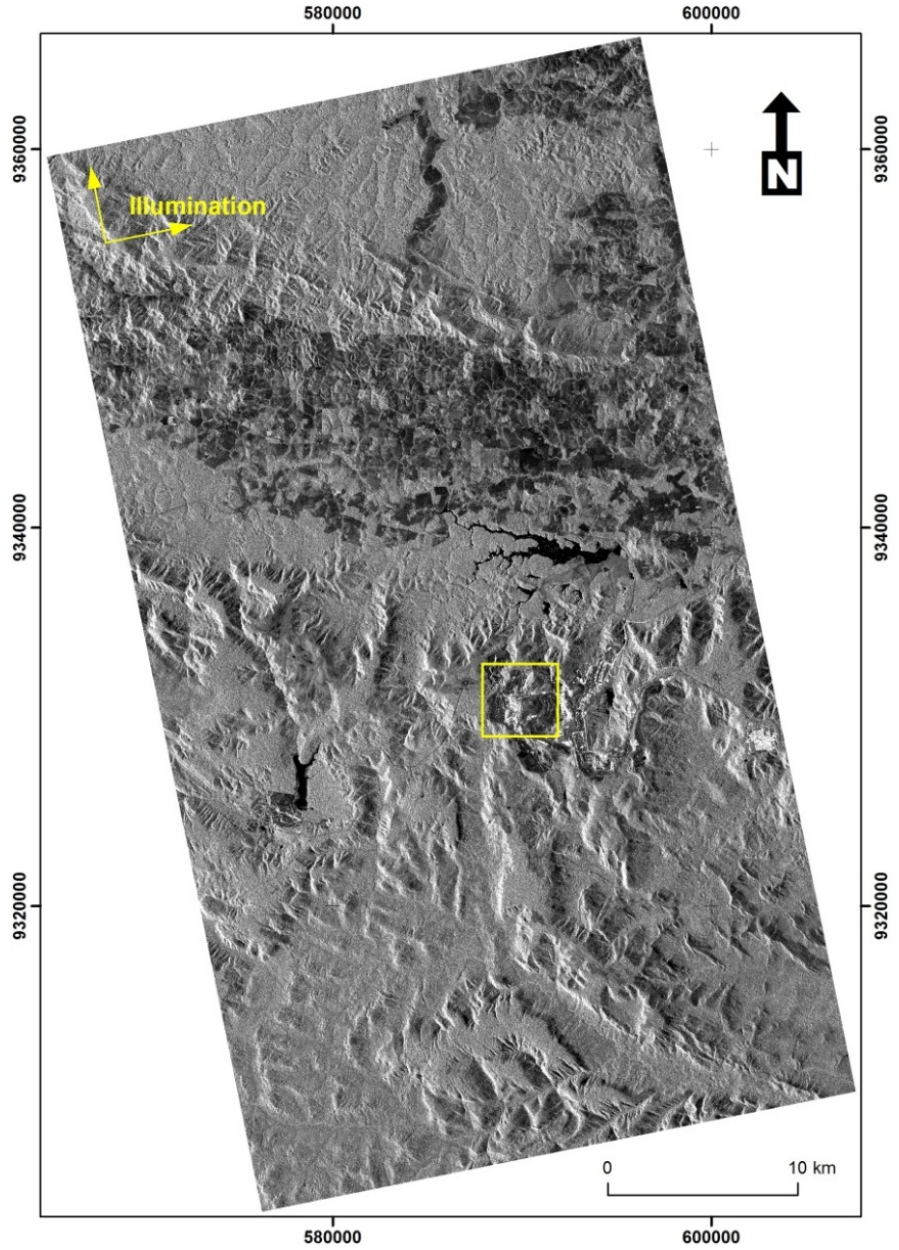

Figure 4. (a) Aspect map (azimuth) and (b) Slope map superimposed on a GeoEye-1 colored composition.

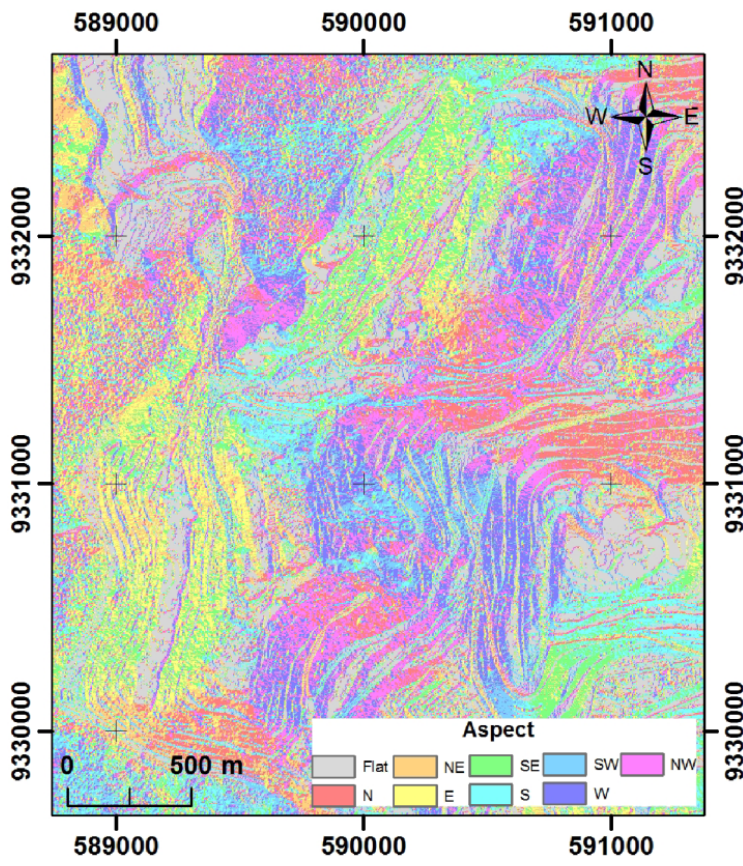

(a)

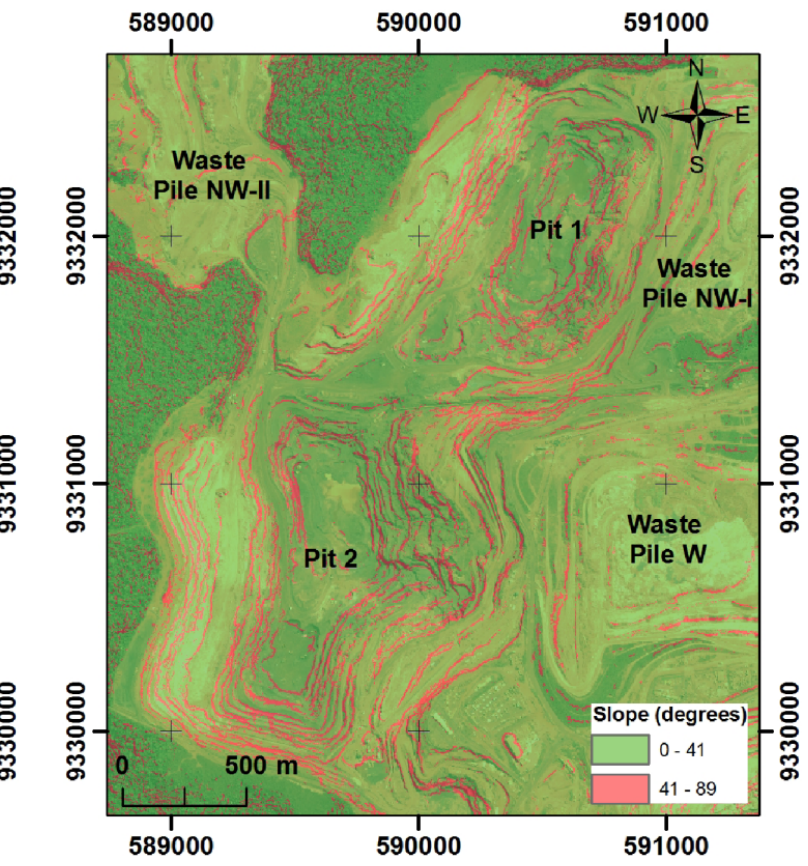

(b) 
Figure 5 illustrates the temporal decorrelation problem between the first and the last SAR scene used in the IPTA radar processing. As can be seen, there are significant changes in the topographic surface due to mining activities in the west flanks of pits 1 and 2, as well as in the waste piles, NW-I and NW-II. The interferometric coherence map represents a way of quantifying this effect, where darker regions indicate strong changes, and lighter regions the opposite. According to Figure 5c, there was a significant change in the last SAR scene (09-23-2012) in comparison with the first one (03-20-2012). However, as one can see through the visual inspection of the SAR scenes, particularly over the waste pile $\mathrm{W}$, mining activities are not the only factor affecting coherence.

Figure 5. The figures depict the decorrelation effect of radar scenes over N4W iron mine: (a) and (b) amplitude scenes acquired on 20 March and 23 September 2012, respectively; and (c) coherence map derived from the SAR scenes. White areas indicate no surface changes while black areas indicate the opposite. For the locations of pits and mine waste piles refer to Figure $4 \mathrm{~b}$. Perpendicular baseline $=231.5 \mathrm{~m}$. The pictures are in slant range coordinates.
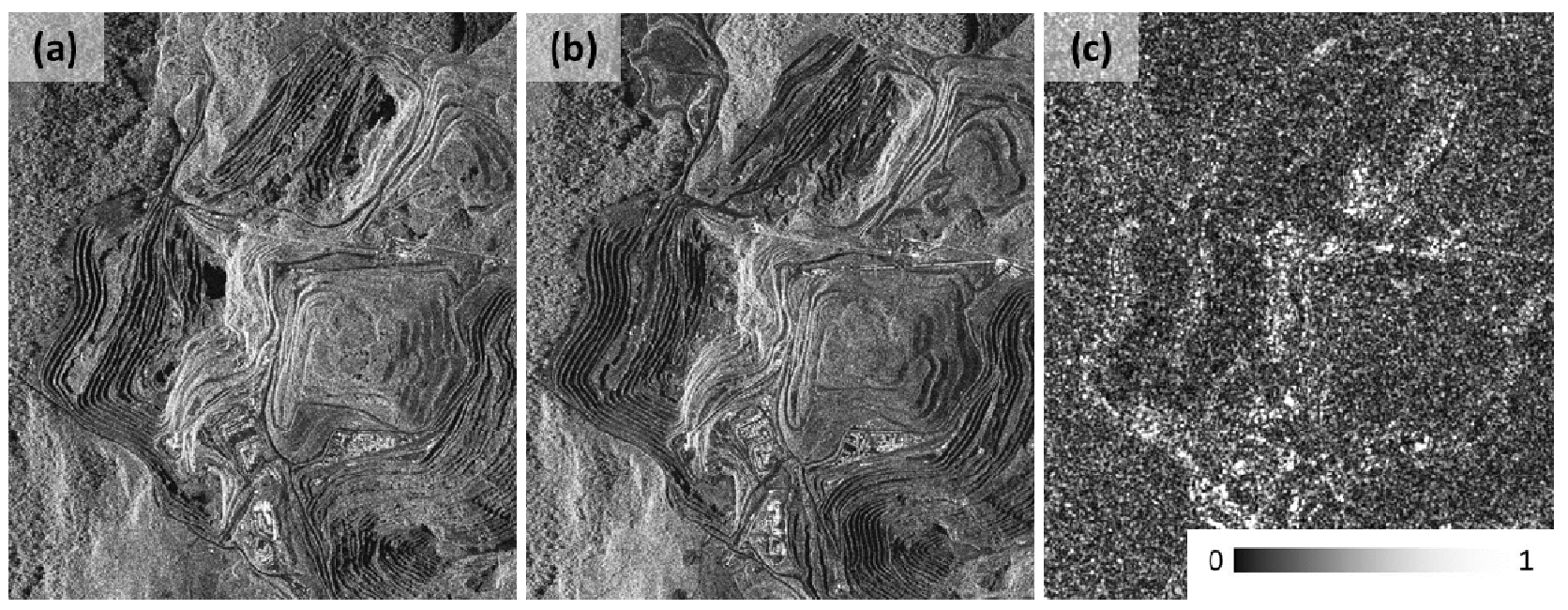

Figure 6 depicts the PS population and deformation rates superimposed on the lithostructural and geomechanical maps of the N4W mine. The IPTA processing allowed the identification of 43.482 PS in an area of near $15 \mathrm{~km}^{2}$, even in the regions affected by geometric distortion effects described previously. The figures also show that there is a wide spatial coverage of persistent scatterers, 2.898 $\mathrm{PS} / \mathrm{km}^{2}$. This result represents a large number, as the N4W mine is not urbanized, and is subjected to intense rains and constant surface changes due to mining activities (Figure 5). One must keep in mind, that the displacement rates were measured along the LOS. Figure 6 shows that most of the study area can be considered to be stable during the time span of the scene acquisitions (greenish regions). Nevertheless, very high deformation rates were detected over the waste piles $(\sim 312 \mathrm{~mm} / \mathrm{year})$ and small deformation rates ( $<40 \mathrm{~mm} /$ year) were mostly detected in the cut slopes of the left flank of N4W mine. The accuracy of the detected deformation rates can be evaluated by their temporal standard deviation. The high standard deviation values observed $\left(\sigma_{\text {average }}=5.6 \mathrm{~mm} /\right.$ year $)$ are due to the small number of SAR scenes processed and the short observation period (seven months). 
Figure 6. LOS deformation measurements ( $\mathrm{mm} / \mathrm{year})$ derived from the IPTA processing of 18 SAR scenes superimposed on the generalized lithostructural (left) and on the geomechanical map (right) of the N4W iron mine. The background map was adapted from [15] and it uses an outdated topographic base map. For details about the highlighted circled areas, consult the text. The picture (below) depicts the re-sloping of a highly weathered rock mass composed of metavolcanic rocks (RMR V). View to southwest. Picture taken on 25 October 2012.
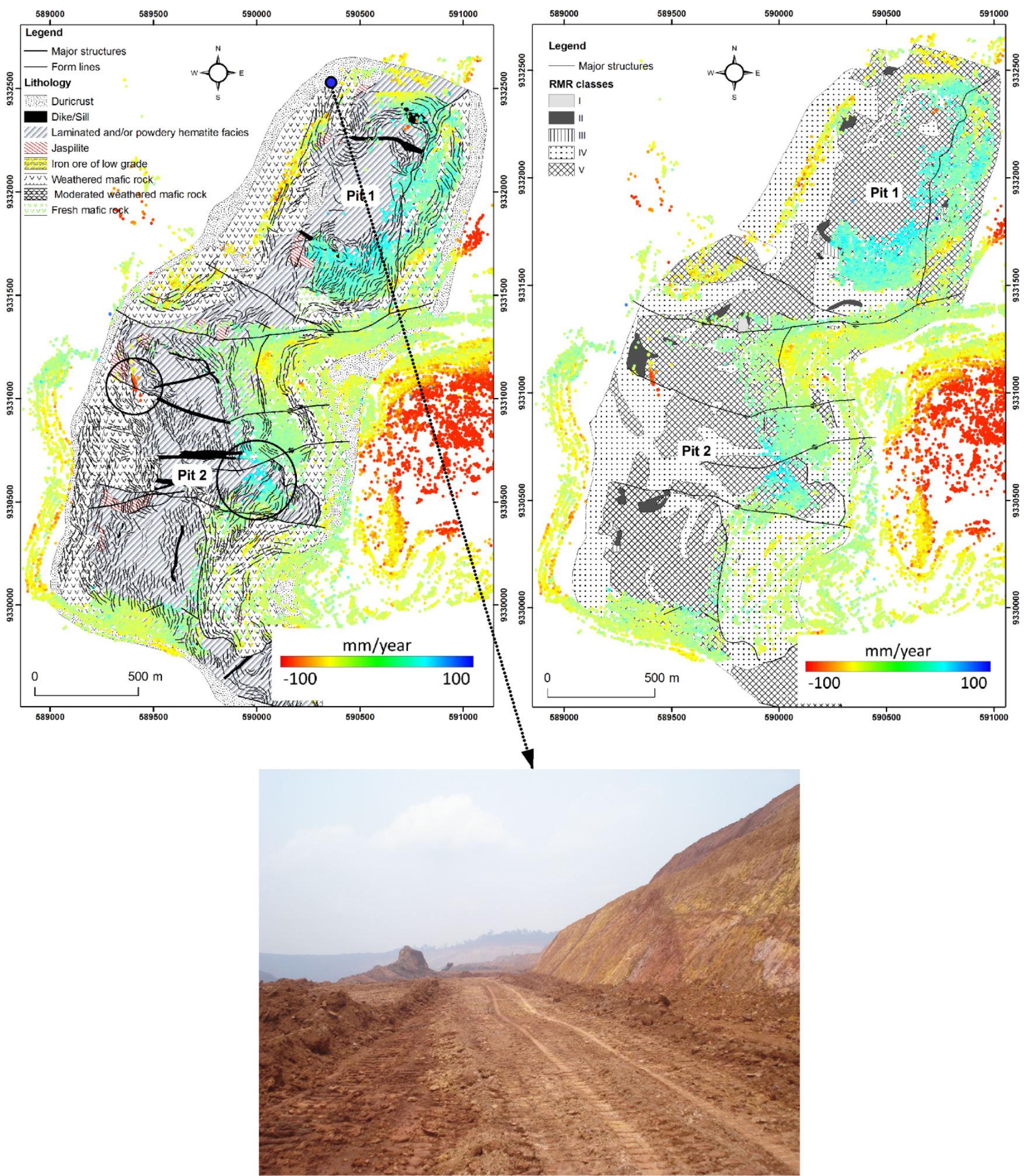
Since surface deformations and slope stability are essential issues to mining operations in the area, a network of leveling measurement points, using total station and reflecting prisms, was available for the validation to establish vertical movements. In order to make representative comparisons, the vertical optical leveling data was converted to the LOS of the TSX-1 satellite [50]. The conversion was done by multiplying the optical leveling measurements by the cosine of the incidence angle $\left(\theta \approx 41^{\circ}\right)$. This procedure provided $1.5 \mathrm{~mm}$ of accuracy, and was achieved by using the method of uncertainty propagation. With the purpose of ensuring that the values obtained by both, interferometry and optical leveling, refer to the same place, we selected only the closest data pairs. It is important to mention that the planimetric accuracy of the orthorectified GeoEye-1 scene is one meter only. The available field data is related to six sites located in the cut slopes that lead to the mine waste pile NW-I. These slopes are constituted of highly weathered metavolcanic rocks (Figure 7).

Figure 7. The left-side picture corresponds to the optical leveling and PS locations. The background image is a GeoEye-1 colored composition. The right-side picture is a general view of the monitored slopes. The picture was taken on 15 March 2012.

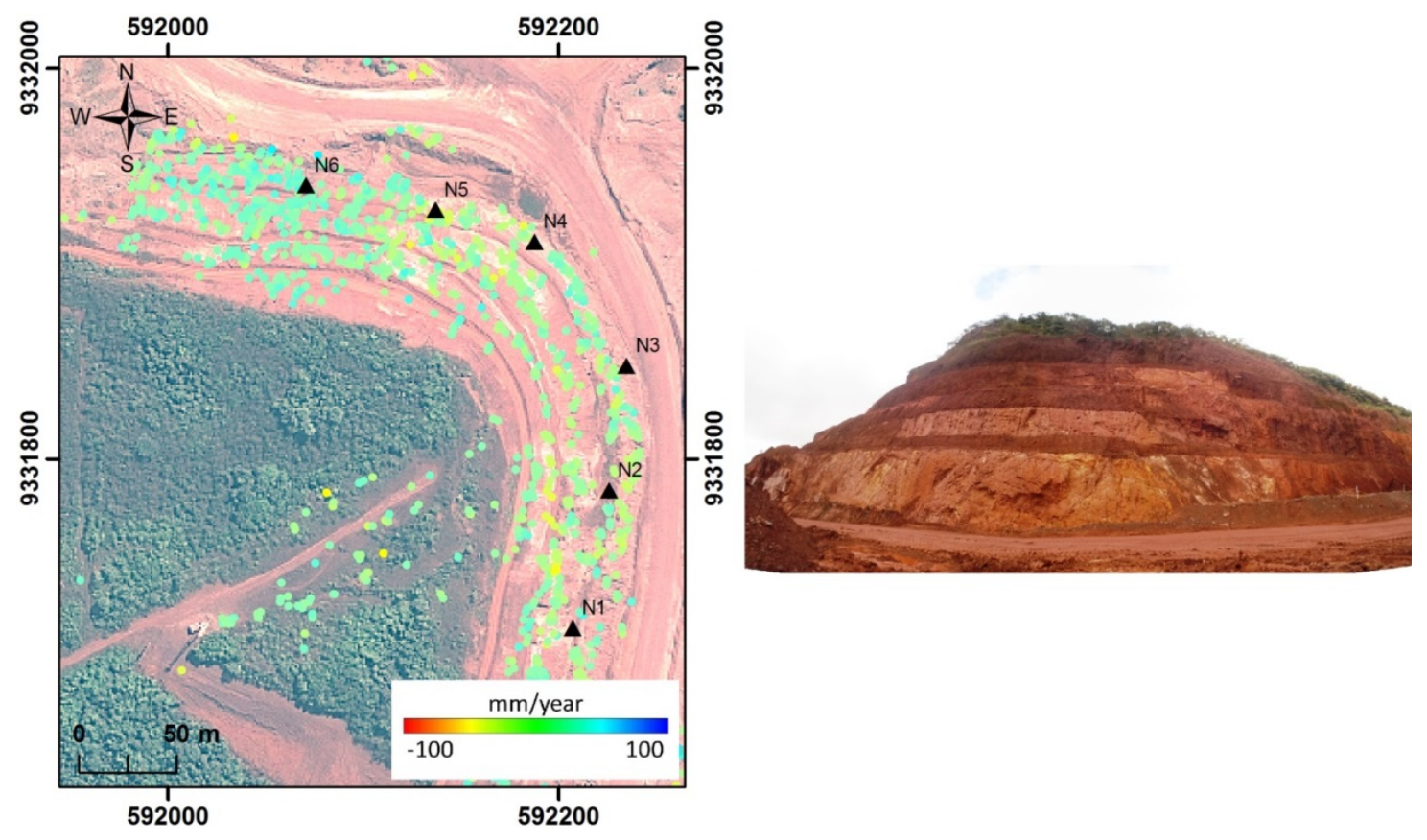

Figure 8 shows the plots of displacement values versus time for both optical leveling and interferometric (IPTA) approaches for the six sites. As one can see, the agreement is poor. Most of this result was also confirmed by the Mann-Whitney non-parametric statistical test, adopting a level of 5\% of significance. The divergence of the measurements can be due to the effect of thermal expansion/contraction as they were taken on different days and at different times, as well as to the high values of standard deviation. Even taking these factors into account, both approaches showed small values of deformation $(<|12 \mathrm{~mm}|)$. Moreover, the results do not show any distinguishable deformation trend, which indicates that the slope cuts were stable during the time span. This result was also confirmed by the local geotechnical team of Vale S.A. mining company. 
Figure 8. LOS deformation history derived from optical leveling and the IPTA processing for the period from June to September 2012, for the six sites. The differences in spatial location between the PS and the optical leveling are of few meters. The accuracy of each approach is indicated by its standard deviation.
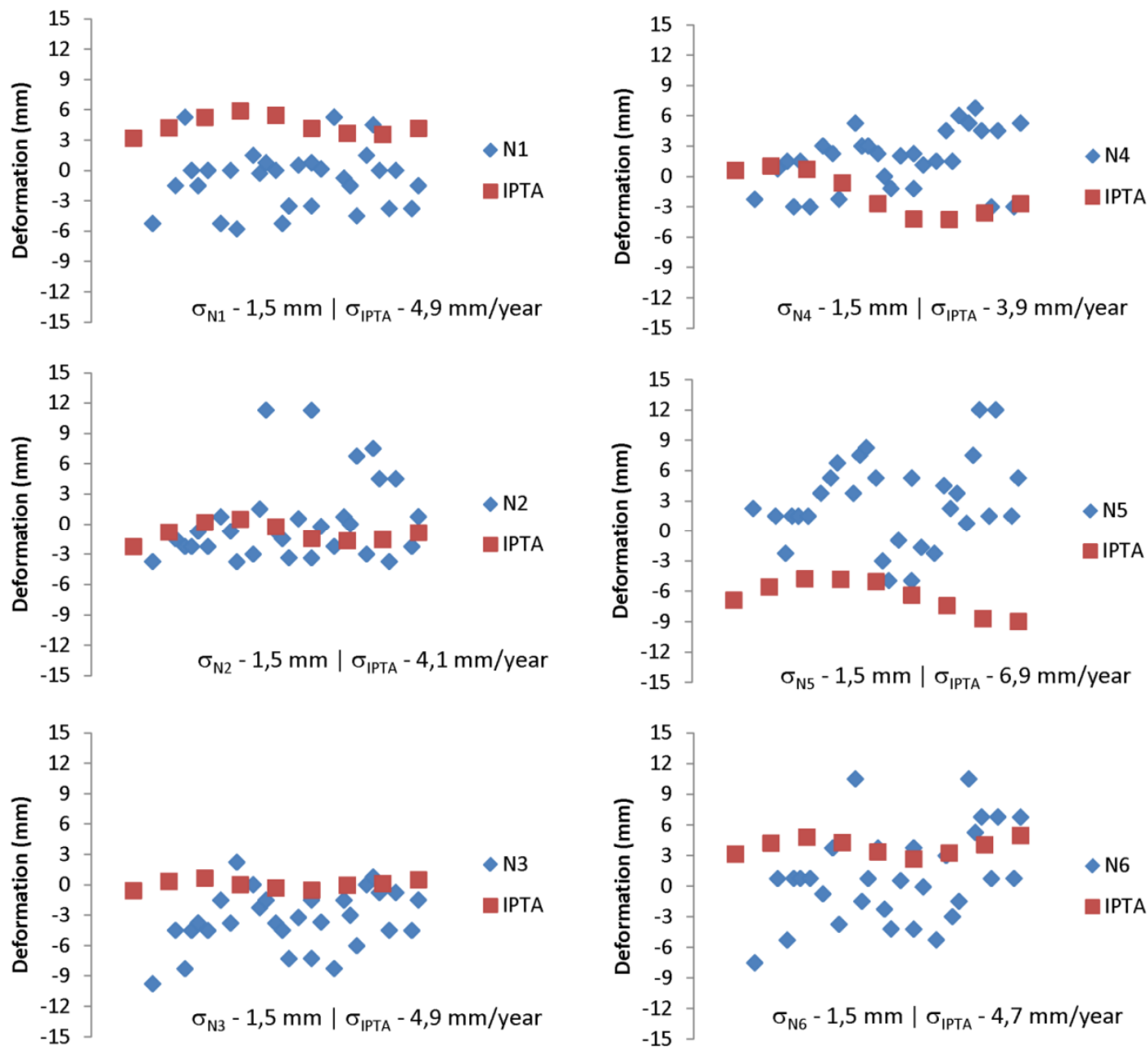

\section{Discussions}

The LOS deformation maps coupled with geological and field data indicate that the displacements found over the mine waste piles are due to the vertical compaction or to consolidation mechanisms of the discarded material. Reference [51] describes that, under dry conditions, settlements up to $7 \%$ of the waste dump height have typically been reported. Thereby, for the waste piles of the study area, vertical settlements of a few meters are expected. The results also showed that the deformation rates tend to decrease radially from the top to the base of the waste pile $\mathrm{W}$, which is an indication of its stability.

With respect to the small deformation rates detected over the cut slopes in the left flank of N4W mine, most of them can be attributed to the accommodation of highly weathered metavolcanic rocks and to small variations in the slope geometry (orientation, inclination, and height). In these areas poor rock masses were mapped (RMR IV and V), in which structures strike nearly parallel to the local slope orientation (Figure 6). Looking in more detail this region, it can be seen two small areas in Pit 2, highlighted in Figure 6 (circles), near to the geological contact between ironstones and country rocks 
that have shown peculiar deformation patterns. Both areas overlie or are limited by E-W-trending faults. As most of the rock masses show to be very fractured, it is possible to consider that part of the detected deformation was influenced somehow by these major structures. Another key factor that must be taken into account to explain the tiny deformations observed in the area located in the west flank of Pit 2, is the ore exploitation in downhill cut slopes, which can be clearly visible in the amplitude SAR scenes.

\section{Concluding Remarks}

This study showed the applicability of the PSI technique using ascending TerraSAR-X scenes in the monitoring of an active open pit mine in the tropical rainforest environment of the Amazon. The IPTA processing allowed the identification of a large number of widely distributed persistent scatterers even in a complex area, such as the N4W iron mine, in Carajás, Brazil. Moreover, it showed that the study area was stable during the time span in agreement with field observations. Nevertheless, high deformation rates up to $312 \mathrm{~mm} /$ year were detected on the mine waste pile $\mathrm{W}$. The quality of the results is somewhat reduced as compared to cases where much longer time series were available.

The investigation has shown that relevant high-resolution ground deformations can be systematically provided including the overall stability around and within pits, waste piles, infrastructures, etc. However, several aspects need to be addressed. Firstly, the PSI technique is not capable of providing real-time data. One possible solution is to acquire high-frequency images (e.g., every four days) coupled with rapid SAR processing. Recently, [52] have shown a different approach in order to manage such a problem. Secondly, the technique faces limitations due to SAR viewing geometry. As an alternative, we strongly recommend the use of SAR scenes acquired in both ascending and descending orbits, which would also provide a more complete and clear understanding of the deformation patterns. With ascending and descending passes, both sides of the pit can be viewed and vertical and horizontal deformation components can be derived. In addition, the use of amplitude information can be important to determine where strong changes are occurring.

The next step of this work is to evaluate the behavior of the N4W mine slopes and their surroundings in the wet season, which is considered the most critical period.

\section{Acknowledgments}

This research was developed under the scope of the Project FAPESP-Vale-INPE (Grant \# 2010/51267-9), which the first author would like to acknowledge for his Ph.D. scholarship (Grant \# 2011/23068-4, São Paulo Research Foundation - FAPESP). The authors would like also to thank Vale S.A. mining company for providing geological and leveling data and for the field work support. The authors are grateful to Maurício Galo (UNESP-Presidente Prudente, Brazil) and Camilo Daleles Rennó (INPE-São José dos Campos, Brazil) for helpful suggestions on geometrical and statistical treatment of the optical leveling data.

\section{Conflicts of Interest}

The authors declare no conflict of interest. 


\section{References}

1. Instituto Brasileiro de Mineração. Informações e Análises da Economia Mineral Brasileira, 6th ed.; IBRAM: Brasília, Brazil, 2011.

2. Sá, G.; Soares, F.; Pires, M.H.A. Condicionantes de Ruptura na Mina de N4WN, Carajás-PA. In Proceedings of Anais do $12^{\circ}$ Congresso Brasileiro de Geologia de Engenharia e Ambiental, Porto de Galinhas, Brazil, 23-27 November 2008.

3. Wieczorek, G.F.; Snyder, J.B. Monitoring Slope Movements. In Geological Monitoring; Young, R., Norby, L. Eds.; Geological Society of America: Boulder, CO, USA, 2009; pp. 245-271.

4. Berardino, P.; Costantini, M.; Franceschetti, G.; Iodice, A.; Pietranera, 1.; Rizzo, V. Use of differential SAR interferometry in monitoring and modelling large slope instability at Maratea (Basilicata, Italy). Eng. Geol. 2003, 68, 31-51.

5. Raucoules, D.; Maisons, C.; Carnec, C.; le Movelic, S.; King, C.; Hosford, S. Monitoring of slow ground deformation by ERS radar interferometry on the Vauvert Salt Mine (France): comparison with ground-based measurement. Remote Sens. Environ. 2003, 88, 468-478.

6. Ferretti, A.; Prati, C.; Rocca, F. Permanent Scatterers in SAR Interferometry. IEEE Trans. Geosci. Remote Sens. 2001, 39, 8-19.

7. Ferretti, A.; Prati, C.; Rocca, F. Nonlinear subsidence rate estimation using permanent scatterers in Differential SAR Interferometry. IEEE Trans. Geosci. Remote Sens. 2000, 38, 2202-2212.

8. Farina, P.; Colombo, D.; Fumagalli, A.; Marks, F.; Moretti, S. Permanent Scatterers for landslide investigations: outcomes from the ESA-SLAM Project. Eng. Geol. 2006, 88, 200-217.

9. Rott, H.; Nagler, T. The contribution of radar interferometry to the assessment of landslide hazards. Adv. Space Res. 2006, 37, 710-719.

10. Colesanti, C.; Wasowski, J. Investigating landslides with space-borne Synthetic Aperture Radar (SAR) interferometry. Eng. Geol. 2006, 88, 173-199.

11. Strozzi, T.; Farina, P.; Corsini, A.; Ambrosi, C.; Thuring, M.; Zilger, J.; Wiesmann, A.; Wegmuller, U.; Werner, C. Survey and monitoring of landslide displacements by means of L-band satellite SAR interferometry. Landslide 2005, 2, 193-201.

12. Hilley, G.E.; Bürgmann, R.; Ferretti, A.; Novali, F.; Rocca, F. Dynamics of slow-moving landslides from permanente scatterer analysis. Science 2004, 304, 1952-1955.

13. Colesanti, C.; Ferretti, A.; Prati, C.; Rocca, F. Monitoring landslides and tectonic motion with the Permanent Scatterers technique. Eng. Geol. 2003, 68, 3-14.

14. Kimura, H; Yamaguchi, Y. Detection of landslide areas using satellite radar interferometry. Photogramm. Eng. Remote Sens. 2000, 66, 337-344.

15. BVP Engenharia LTDA. Mapeamento Litoestrutural e Litogeomecânico da Mina N4WN; Relatório Interno-VL 070-10-E-CA-RT-03-55-00; BVP Engenharia LTDA: Belo Horizonte. Brazil, 2009; p. 75.

16. DOCEGEO. Revisão litoestratigráfica da Província Mineral de Carajás. In Proceedings of Anais do XXXV Congresso Brasileiro de Geologia, Belém, Brazil, 6-13 November 1988; pp. 11-54.

17. Gibbs, A.G.; Wirth, K.R.; Hirata, W.K.; Olszewski, W.J. Age and composition of the Grão-Pará Group volcanics, Serra dos Carajás. Revista Brasileira de Geociências 1986, 16, 201-211. 
18. Faraco, M.T.L.; Marinho, P.A.C.; Vale, A.G.; Costa, E.J.S.; Maia, R.G.N.; Ferreira, A.L.; Valente, C.R.; Lacerda Filho, J.V.; Moreton, I.C.; Camargo, M.A.; et al. Folha SB.22-Araguaia. In Carta Geológica do Brasil ao Milionésimo, Sistema de Informações Geográficas; Schobbenhaus, C., Gonçalves, J.H., Santos, J.O.S., Abram, M.B., Leão Neto, R., Matos, G.M.M., Vidotti, R.M., Ramos, M.A.B., Jesus, J.D.A., Eds.; CPRM, Programa Geologia do Brasil: Brasília, Brazil, 2004; CD-ROM.

19. Veneziani, P.; Santos, A.R.; Paradella, W.R. A evolução tectono-estratigráfica da Província Mineral de Carajás: um modelo com base em dados de sensores remotos orbitais (SAR-C RADARSAT-1, TM-Landsat-5), aerogeofísica e dados de campo. Revista Brasileira de Geociências 2004, 34, 67-78.

20. Beisiegel, V.R.; Bernardelli, A.L.; Drummond, N.F.; Ruff, A.W.; Tremaine, J.W. Geologia e recursos minerais da Serra dos Carajás. Revista Brasileira de Geociências 1973, 3, 215-242.

21. Araújo, O.J.B.; Maia, R.G.N.; João, X.S.J.; Costa, J.B.S. A megaestruturação Arqueana da Folha Serra dos Carajás. In Proceedings of Anais do VII Congresso Latino-Americano de Geologia, Belém, Brazil, 6-13 November 1988; pp. 324-338.

22. Pinheiro, R.V.L. e Holdsworth, R.E. The structure of the Carajás N-4 Ironstone deposit and associated rocks: relationship to Archean strike-slip tectonics and basement reactivation in Amazon region, Brazil. J. South Amer. Earth Sci. 1997, 10, 305-319.

23. Costa, J.B.S.; Araujo, J.B.; Santos, A.; Jorge Joao, X.S.; Macambira, M.J.B.; Lafon, J.M. A província mineral de Carajás: aspectos tectono-estruturais, estratigráficos e geocronológicos. Boletim Museu Paraense Emílio Goeldi 1995, 7, 199-235.

24. Lima, F.D.; Pinheiro, R.V.L. Formação Gorotire: considerações sobre uma unidade siliciclástica particular da Serra dos Carajás-PA. In Proceedings of Anais do VI Simpósio de Geologia da Amazônia, Manaus, Brasil, 13-17 June 1999; pp. 201-224.

25. Nogueira, A.C.R.; Truckenbrodt, W.; Costa, J.B.S; Pinheiro, R.V.L. Formação Águas Claras, Pré-Cambriano da Serra dos Carajás. Redescrição e redefinição. Boletim do Museu Paraense Emilio Goeldi 1995, 7, 177-197.

26. Hirata, W.K.; Rigon, J.C.; Kadekaru, K.; Cordeiro, A.A.C.; Meireles, E.M. Geologia Regional da Província Mineral de Carajás. In Proceedings Anais do I Simpósio de Geologia da Amazônia, Belém, Brazil, May 1982; pp. 100-109.

27. Machado, N.; Lindenmayer, Z.; Krogh, T.E.; Lindenmayer, D. U-Pb geochronology of Archean magmatism and basement reactivation in the Carajás area, Amazon shield, Brazil. Precambrian Res. 1991, 49, 329-354.

28. Lindenmayer, Z.G.; Laux, J.H.; Teixeira, J.B.G. Considerações sobre a origem das formações ferríferas da Formação Carajás, Serra dos Carajás. Revista Brasileira de Geociências 2001, 31, $21-28$.

29. Olszewski, W.J.; Wirth, K.R.; Gibbs, A.K.; Gaudette, H.E. The age, origin, and tectonics of the Grão Pará Group and associated rocks, Serra dos Carajás, Brazil: Archean continental volcanism and rifting. Precambrian Res. 1989, 42, 229-254.

30. Dall'Agnol. R.; Costi, H.T.; Leite, A.A.S.; Magalhaes, M.S.; Teixeira, N.P. Rapakivi granites from Brazil and adjacent areas. Precambrian Res. 1999, 95, 9-39. 
31. Dall'Agnol, R.; Souza, Z.S.; Althoff, F.J.; Barros, C.E.M.; Leite, A.A.S.; Jorge Joao, X.S. General Aspects of the Granitogenesis of the Carajas Metallogenic Province. In Proceedings of the II Intern. Symp. Gran. Assoc. Miner., Excursions Guide, Salvador, Brazil, 24-29 August 1997; pp. 135-161.

32. Grainger, C.J.; David, I.G.; Tallarico, F.H.B.; Fletcher, I.R. Metallogenesis of the Carajás Mineral Province, southern Amazon Craton, Brazil: varying styles of Archean through Paleoproterozoic to Neoproterozoic base-and precious-metal mineralization. Ore Geol. Rev. 2008, 33, 451-489.

33. Dias, G.S.; Macambira, M.J.B.; Dall'Agnol, R.; Soares, A.D.V.; Barros, C.E.M. Datações de Zircões de sill de Metagabro: Comprovação da Idade Arqueana da Formação Águas Claras, Carajás-Pará. In Proceedings of Anais do V Simpósio de Geologia da Amazônia, Belém, Brazil, 27 May-2 June 1996; pp. 376-379.

34. Trendall, A.F.; Basei, M.A.S.; Laeter, J.R.; de Nelson, D.R. SHRIMP zircon U-Pb constraints on the age of the Carajás formation, Grão Pará Group, Amazon Craton. J. South Am. Earth Sci. 1998, $11,265-277$.

35. Costa, J.B.S.; Pinheiro, R.V.L.; João, X. da S.; Araújo, O.J.B. Esboço estrutural do Proterozóico médio da Amazônia Oriental. Boletim do Museu Paraense Emílio Goeldi 1991, 3, 9-24.

36. Sá, G. Caracterização litoestrutural e parametrização geomecânica das superfícies de ruptura em taludes da mina de N4E, Carajás-PA. Dissertação de Mestrado. Universidade Federal de Ouro Preto, Ouro Preto, 2010.

37. International Society for Rock Mechanics (ISRM). Rock Characterization, Testing and Monitoring Suggested Methods; Pergamon Press: London, UK, 1981; p. 211.

38. Bieniawski, Z.T. Engineering Rock Mass Classifications: A Complete Manual for Engineers and Geologists in Mining, Civil and Petroleum Engineering; John Wiley \& Sons: New York, NY, USA, 1989; p. 272.

39. Madsen, S.N.; Zebker, H.A. Imaging Radar Interferometry. In Principles \& Applications of Imaging Radar: Manual of Remote Sensing, 3rd ed.; Henderson, F.M., Lewis, A.J., Eds.; John Wiley \& Sons, Inc.: Danvers, MA, USA, 1998; Volume 2, pp. 359-380.

40. Graham, I.C. Synthetic interferometer radar for topographic mapping. Proc. IEEE 1974, 62, 763-768.

41. Massonnet, D.; Rossi, M.; Carmona, C.; Adragna, F.; Peltzer, G.; Fiegl, K.; Rabaute, T. The displacement field of the Landers earthquake mapping by radar interferometry. Nature 1993, 364, 138-142.

42. Paradella, W.R.; Mura, J.C.; Gama, F.F.; Santos, A.R. Radar Interferometry in Surface Deformation Detection with Orbital Data. Revista Brasileira de Cartografia 2012, 64, 797-811.

43. Zhou, X.; Chang, N.B.; Li, S. Applications of SAR interferometry in Earth and environment science research. Sensors 2009, 9, 1876-1912.

44. Kampes, B.M. Radar Interferometry: Persistent Scatterer Technique; Springer: Dordrecht, The Netherlands, 2006; p. 211.

45. Hooper, A.; Zebker, H.; Segall, P.; Kampes, B. A new method for measuring deformation on volcanoes and other natural terreins using InSAR persistent scatterers. Geophys. Res. Lett. 2004, 31, L23611. 
46. Adam, N.; Kampes, B.; Eineder, M.; Worawattanamateekul, J.; Kircher, M. The Development of a Scientific Permanent Scatterer System. In Proceedings of Joint Workshop of ISPRS WG I/2,I/5 and IC WG II/IV and EARSeL Special Interest Group 3D Remote Sensing, Hannover, Germany, 6-8 October 2003; pp. 1-6.

47. Duro, J.; Closa, J.; Biescas, E.; Crosetto, M.; Arnaud, A. High Resolution Differential Interferometry Using Time Series of ERS and EVISAT SAR Data. In Proceedings of the FRINGE, Frascati, Italy, 2-5 December 2003; Published on CDROM. p. 72.1.

48. Werner, C.; Wegmuller, U.; Strozzi, T.; Wiesmann, A. Interferometric Point Target Analysis for Deformation Mapping. In Proceedings of the IGARSS'03, Toulouse, France, 21-25 July 2003; pp. $4362-4364$.

49. Paradella, W.R.; Cheng, P. Using Geoeye-1 stereo data in mining application: automatic DEM generation. Geoinformatics 2013, 16, 10-12.

50. Colesanti, C.; Ferretti, A.; Prati, C.; Rocca, F. Comparing GPS, Optical Leveling and Permanent Scatterers. In Proceedings of the IGARSS'01, Sydney, Australia, 9-13 July 2001; pp. 2622-2624.

51. Orman, M.; Peevers, R.; Sample, K. Waste Piles and Dumps. In SME Mining Engineering Handbook, 3rd ed.; Darling, P., Ed.; SME: Englewood, CO, USA, 2011; Volume 1, pp. 667-680.

52. Allasia, P.; Manconi, A.; Giordan, D.; Baldo, M.; Lollino, G. ADVICE: a new approach for near-real-time monitoring of surface displacements in landslide hazard scenarios. Sensors 2013, $13,8285-8302$.

(C) 2013 by the authors; licensee MDPI, Basel, Switzerland. This article is an open access article distributed under the terms and conditions of the Creative Commons Attribution license (http://creativecommons.org/licenses/by/3.0/). 